\title{
EVALUATION OF HOOP RESIDUAL STRESS VARIATIONS IN THE THICKNESS OF DISSIMILAR WELDED PIPES BY USING THE LCR ULTRASONIC WAVES
}

\author{
Yashar Javadi, Grzegorz, M. Krolczyk, Sergej Hloch
}

Original scientific paper

Stress measurement by using ultrasonic waves is based on acoustoelasticity law, i. e. the relation between stress and wave velocity in engineering materials. Longitudinal critically refracted $\left(L_{\mathrm{CR}}\right)$ wave is a popular ultrasonic wave in the ultrasonic stress measurement application. The $L_{\mathrm{CR}}$ wave is a bulk longitudinal wave that travels within an effective depth underneath the surface. This paper evaluates hoop residual stress variation in the thickness of a pipe. The pipe is manufactured by welding two dissimilar pipes from AISI stainless steel 304 and carbon steel A106-B type. The residual stresses variations in the thickness of pipe are measured by using four different frequencies of transducers while the nominal frequencies are $1 \mathrm{MHz}, 2 \mathrm{MHz}, 4$ $\mathrm{MHz}$ and $5 \mathrm{MHz}$. Using different frequencies enables the $L_{\mathrm{CR}}$ waves to penetrate in different depths and measure the bulk stresses of pipe. It has been shown that the stress difference between inner and outer surfaces of pipes and also between the stainless steel and carbon steel side of dissimilar pipe can be evaluated by using the $L_{\mathrm{CR}}$ waves.

Keywords: acoustoelastic effect; dissimilar welded joint; $L_{\mathrm{CR}}$ wave; ultrasonic stress measurement; welding residual stress

\section{Ocjena varijacija cirkularnih zaostalih naprezanja u debljini različito zavarenih cijevi pomoću $L_{c R}$ ultrazvučnih valova}

Izvorni znanstveni članak

Mjerenje naprezanja pomoću ultrazvučnih valova temelji se na akustičnoelastičnom zakonu, t.j.odnosu između naprezanja i brzine valova u inženjerskim materijalima. Uzdužni kritički lomljen - Longitudinal critically refracted $\left(L_{\mathrm{CR}}\right)$ val je popularni ultrazvučni val u primjeni ultrazvučnog mjerenja naprezanja. $L_{\mathrm{CR}}$ val je masovni uzdužni val koji putuje na efektivnoj dubini ispod površine. U ovom radu procjenjuje se varijacija cirkularnog zaostalog naprezanja u debljini cijevi. Cijev je proizvedena zavarivanjem dviju različitih cijevi od nehrđajućeg čelika AISI 304 i ugljičnog čelika tipa A106-B. Varijacije zaostalih naprezanja u debljini cijevi mjere se pomoću četiri različite frekvencije pretvarača, dok su nominalne frekvencije $1 \mathrm{MHz}, 2 \mathrm{MHz}, 4$ $\mathrm{MHz}$ i $5 \mathrm{MHz}$. Uporabom različitih frekvencija omogućeno je $L_{\mathrm{CR}}$ valovima da prodru do različitih dubina i mjere veličinu naprezanja cijevi. Pokazalo se da se razlika u naprezanju između unutarnje i vanjske površine cijevi i također između strane cijevi od nehrđajućeg čelika i one od ugljičnog čelika može procijeniti pomoću $L_{\mathrm{CR}}$ valova.

Ključne riječi: akustičnoelastični učinak; različito zavaren spoj; $L_{\mathrm{CR}}$ val; ultrazvučno mjerenje naprezanja; zaostalo naprezanje kod zavarivanja

\section{Introduction}

Residual stresses are present in materials without any external pressure, and normally result from deformation heterogeneities appearing in the material. They have very important role in the strength and service life of structures [1]. Welding is an assembly process often used in different industries, especially in the pressure vessel industry. According to the process and temperatures reached during this operation, dangerous thermomechanical stresses may appear in the welded joint. To achieve a proper design of structure and control their mechanical strength in service, it is very important to determine the residual stress levels with a non-destructive method [2]. The high industry request for the stress measurement techniques encouraged development of several methods like X-ray diffraction, incremental hole drilling, and the ultrasonic method. Many studies showed that there is no universal or absolute method that gives complete satisfaction in the non-destructive stress monitoring of the mechanical components. Many parameters such as material, geometry, surface quality, cost, and accuracy of the measurement, etc., must be taken into account in choosing an adequate technique. The ultrasonic technique was selected for stress measurement because it is non-destructive, easy to use, and relatively inexpensive. However, it is slightly sensitive to the microstructure effects (grains size $[3 \div 5]$, carbon rate $[6,7]$, texture $[8 \div 11]$, and structure $[12 \div 14]$ and to the operating conditions (temperature $[15,16]$, coupling $[17,18]$, etc.). The ultrasonic estimation of the residual stresses requires separation between the microstructure and the acoustoelastic effects.

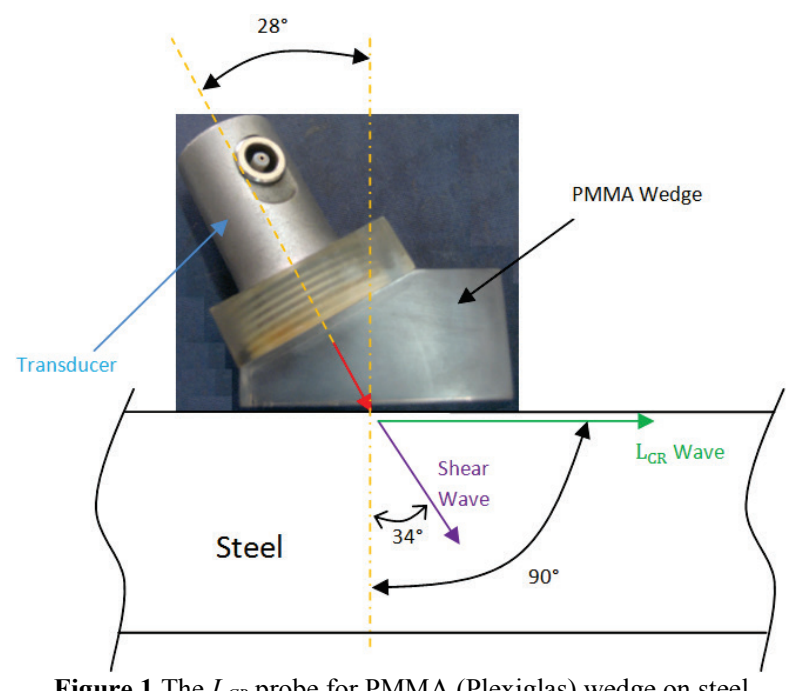

Figure 1 The $L_{C R}$ probe for PMMA (Plexiglas) wedge on steel

\section{Theoretical background}

Within the elastic limit, the ultrasonic stress evaluating technique relies on a linear relationship between the stress and the travel time change, i.e. the acoustoelastic effect $[19,20]$. The $L_{\mathrm{CR}}$ technique uses a special longitudinal bulk wave mode, as shown in Fig. 1, which travels parallel to the surface, particularly propagating beneath the surface at a certain depth. The $L_{C R}$ waves are also called surface skimming longitudinal 
waves (SSLW) by some of the authors. Brekhovskii [21], Basatskaya and Ermolov [22], Junghans and Bray [23], Langenberg et al. [24] had some detailed discussions on the characteristics of the $L_{\mathrm{CR}}$.

Ultrasonic stress measurement techniques are based on the relationship of wave speed in different directions with stress. Fig. 2 shows elements of a bar under tension where the ultrasonic wave propagates in three perpendicular directions. The first index in the velocities represents the propagation direction for the ultrasonic wave and the second represents the direction of the movement of the particles.

In Fig. 2a the wave propagates parallel to the load and $V_{11}$ represents the velocity of the particles in the same direction (longitudinal wave), meanwhile $V_{12}$ and $V_{13}$ represents the velocity in a perpendicular plane (shear waves).

In Fig. $2 b$ and Fig. $2 c$ the waves are propagating in the other directions and the velocities are shown. The $V_{22}$ velocity is for longitudinal waves propagating perpendicular to the stress direction. The sensitivity of these waves to the strain has been established by Egle and Bray [19] in tensile and compressive load tests for a bar of rail steel. The waves with particle motion in the direction of the stress fields showed the greatest sensitivity to stress, and those with particle motions perpendicular to the stress field showed the least. The most considerable variation in travel time with the strain was found for longitudinal waves, followed by the shear waves when the particles vibrate in the direction of the load. The other waves do not show significant sensitivity to the strain.

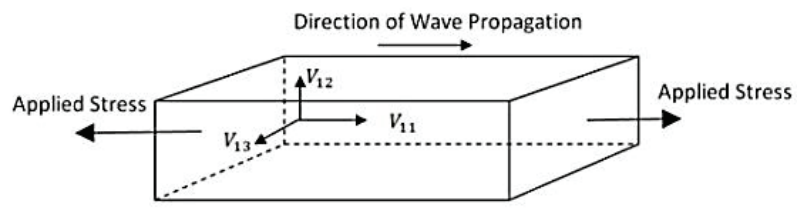

(a)

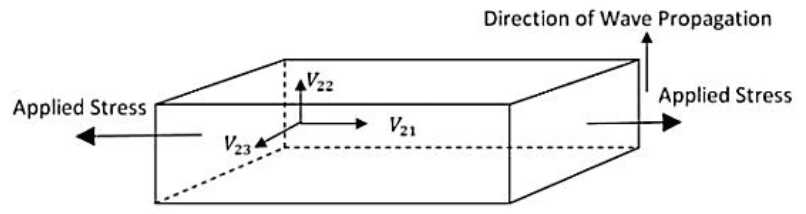

(b)

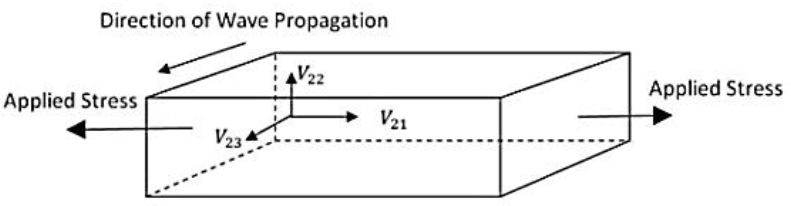

(c)

Figure 2 Velocity of plane wave and stress field in orthogonal directions [25]

The velocities of the longitudinal plane waves traveling parallel to load can be related to the strain $(\alpha)$ by the following expressions:

$\rho_{0} V_{11}^{2}=\lambda+2 \mu+(2 l+\lambda) \theta+(4 m+4 \lambda+10 \mu) \alpha_{1}$, where $\rho_{0}$ is the initial density; $V_{11}$ is the velocity of waves in the direction 1 with particle displacement in the direction $1 ; \lambda, \mu$ the second order elastic constants (Lame's constants); $l, m, n$ are the third order elastic constants; $\theta=\alpha_{1}+\alpha_{2}+\alpha_{3}$ which $\alpha_{1}, \alpha_{2}$ and $\alpha_{3}$ are components of the homogeneous triaxial principal strains. For a state of uniaxial stress, $\alpha_{1}=\varepsilon, \alpha_{2}=\alpha_{3}=-v \times \varepsilon$, where $\varepsilon$ is the strain in the direction 1 and $v$ is the Poisson's ratio. Using these values, Eq. (1) becomes:

$\rho_{0} V_{11}^{2}=\lambda+2 \mu+\left[4(\lambda+2 \mu)+2(\mu+2 m)+v \mu\left(1+\frac{2 \lambda}{\mu}\right)\right] \varepsilon$

The relative sensitivity is the variation of the velocity with the strain and can be calculated by Eq. (3). In this equation, $L_{11}$ is the dimensionless acoustoelastic constant for $L_{\mathrm{CR}}$ waves

$\frac{\mathrm{d} V_{11} / V_{11}}{\mathrm{~d} \varepsilon}=2+\frac{(\mu+2 m)+v \mu(1+2 l / \lambda)}{\lambda+2 \mu}=L_{11}$.

The values of acoustoelastic constants for the other directions can be obtained in the same way. The variation in the $V_{11}$ velocity, controlled by the coefficient $L_{11}$, is much greater than the other ones, indicating that these waves are the best candidates to be used in the stress evaluation. Stress can be calculated by the onedimensional application of the stress-strain relations in elastic solids. Eq. (3) can be rearranged to give the stress variation in terms time-of-flight $\left(\mathrm{d} t / t_{0}\right)$, as shown in the Eq. (4), where $t_{0}$ is the time for the wave to go through a stress free path in the material being investigated.

$\mathrm{d} \sigma=\frac{E\left(\mathrm{~d} V_{11} / V_{11}\right)}{L_{11}}=\frac{E}{L_{11} t_{0}} \mathrm{~d} t$

where $\mathrm{d} \sigma$ is the stress variation $(\mathrm{MPa})$ and $E$ is the elasticity modulus (MPa). The same equation can be used for the other directions of the waves, provided the value of the acoustoelastic coefficient $L$ which is changed. For a fixed probe distance, the travel time of the longitudinal wave decreases in a compressive stress field and increases in a tensile field. The acoustoelastic constant $(L)$ functionally links the stress and the velocity or travel time change.

\section{Experimental procedures}

The materials tested (stainless steel 304 and carbon steel A106-B) are commonly used for pressure vessel applications. Two 8 inch pipes with thickness of $8 \mathrm{~mm}$ are welded in V-groove $\left(60^{\circ}\right.$ included angle) and three passes butt-weld joint. Two rectangular tension test specimens are extracted from the stainless steel and carbon steel plates with the same chemical composition and thickness of pipes to determine the acoustoelastic constant. The measurement device, shown in Fig. 3, includes an Ultrasonic box with integrated pulser and receiver, computer and three normal transducers assembled on a united wedge. A three-probe arrangement is used, with one sender and two receivers in order to eliminate 
environment temperature effect on the travel time. Twelve transducers in four different frequencies are used, their nominal frequencies are $1 \mathrm{MHz}, 2 \mathrm{MHz}, 4 \mathrm{MHz}$ and 5 $\mathrm{MHz}$. Using different frequencies helps to evaluate residual stresses through the thickness of the pipes. The diameters of all the piezoelectric elements are $6 \mathrm{~mm}$. Transducers are assembled on a united PMMA wedge. The ultrasonic box is a $100 \mathrm{MHz}$ ultrasonic testing device which has synchronization between the pulser signal and the internal clock that controls the A/D converter. This allows very precise measurements of the time of flight (better than 1ns).
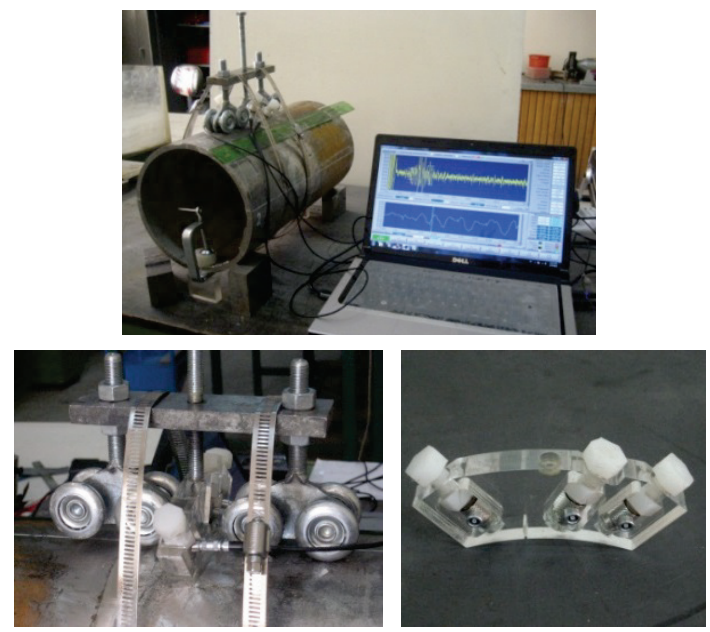

Figure 3 Measurement devices

\subsection{Determination of $L_{C R}$ depth}

When the $L_{\mathrm{CR}}$ technique is applied to an application with limited wall thickness, the depth of the $L_{\mathrm{CR}}$ wave penetration is expected to be a function of frequency, with the low frequencies penetrating deeper than the high frequencies. Since there is not a reliable equation for the relation of $L_{\mathrm{CR}}$ depth and frequency, it should be measured experimentally. Four different frequencies have been used in this work to evaluate the residual stress through the thickness of the plates. Therefore depth of any frequencies can be exactly measured. The setup which is shown in Fig. 4 is used here to measure the depth of the $L_{\mathrm{CR}}$ wave. Two transducers as sender and receiver with the same frequency are used to produce the $L_{\mathrm{CR}}$ wave. A slot is performed between the transducers by milling tool to cut the $L_{\mathrm{CR}}$ wave. The depth of slot is increased step by step and the amplitude of the $L_{\mathrm{CR}}$ wave is measured in each step. When the amplitude of the $L_{\mathrm{CR}}$ wave is equal to the noise, milling process is stopped and the depth of slot represents depth of the $L_{\mathrm{CR}}$ waves for the tested frequency. The material used here is the same as the welded plates. The results of these measurements are shown in Tab. 1. From this table it can be concluded that depths of $L_{\mathrm{CR}}$ wave are $5 \mathrm{~mm}, 2 \mathrm{~mm}, 1,5 \mathrm{~mm}$ and $1 \mathrm{~mm}$ for transducer with nominal frequencies of $1 \mathrm{MHz}, 2$ $\mathrm{MHz}, 4 \mathrm{MHz}$ and $5 \mathrm{MHz}$ respectively.

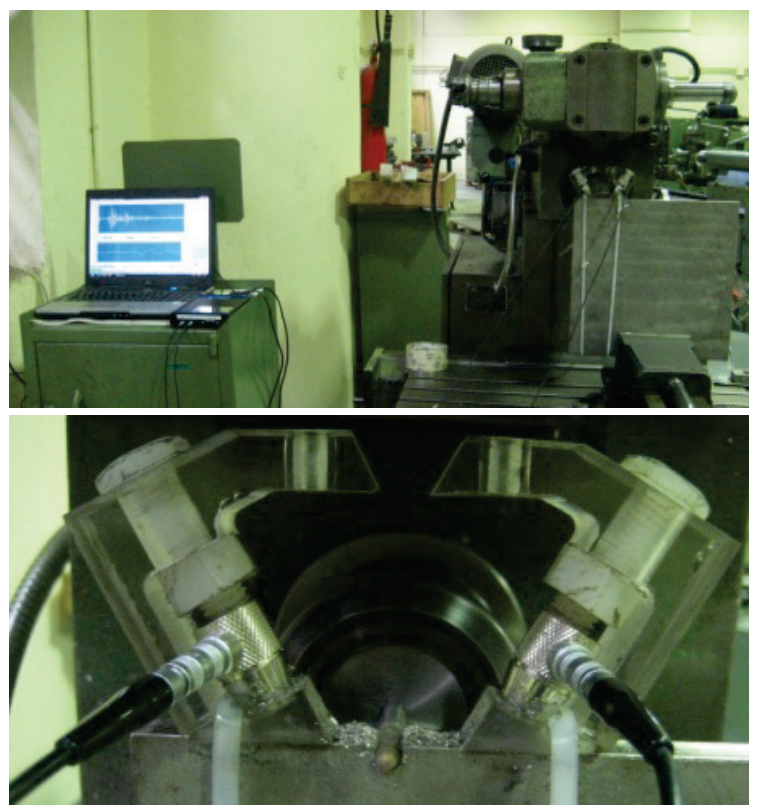

Figure 4 Experimental setup to measure depth of $L_{\mathrm{CR}}$ wave

Table 1 The results of $L_{\mathrm{CR}}$ depth measurement

\begin{tabular}{|c|c|c|c|c|c|c|c|c|c|c|c|}
\hline \multicolumn{3}{|c|}{$1 \mathrm{MHz}$} & \multicolumn{3}{|c|}{$2 \mathrm{MHz}$} & \multicolumn{3}{|c|}{$4 \mathrm{MHz}$} & \multicolumn{3}{|c|}{$5 \mathrm{MHz}$} \\
\hline$D$ & $A$ & $T$ & $D$ & $A$ & $\boldsymbol{T}$ & $D$ & $A$ & $T$ & $D$ & $A$ & $T$ \\
\hline 0 & 0,75 & 13,09 & 0 & 0,55 & 10,91 & 1 & 0,35 & 10,58 & 1 & 0,28 & 10,6 \\
\hline 0,5 & 0,66 & 13,1 & 0,5 & 0,5 & 10,93 & 1,5 & 0,3 & 10,6 & 1,5 & noise & - \\
\hline 1 & 0,6 & 13,14 & 1 & 0,42 & 10,98 & 2 & noise & - & & & \\
\hline 1,5 & 0,54 & 13,18 & 1,5 & 0,4 & 11,02 & & & & & & \\
\hline 2 & 0,49 & 13,21 & 2 & 0,34 & 11,06 & & & & & & \\
\hline 2,5 & 0,47 & 13,26 & 2,5 & noise & - & & & & & & \\
\hline 3 & 0,43 & 13,29 & & & & & & & & & \\
\hline 3,5 & 0,42 & 13,33 & & & & & & & & & \\
\hline 4 & 0,4 & 13,37 & & & & & & & & & \\
\hline 4,5 & 0,33 & 13,37 & & & & & & & & & \\
\hline 5 & 0,2 & 13,37 & & & & & & & & & \\
\hline 5,5 & noise & - & & & & & & & & & \\
\hline
\end{tabular}

\subsection{Evaluation of the calibration constants}

To evaluate the calibration constants (acoustoelastic constant, free stress time-of-flight), two different calibration samples are prepared. The first sample is taken from a stainless steel 304 plate with exactly the same thickness and chemical composition of stainless steel side of the pipes. The second one is extracted from a carbon steel A106-B plate with the same thickness and chemical composition of carbon steel side of the pipes. To evaluate the residual stress from Eq. (4), the value $t_{0}$ is measured directly from the stress-free samples and the 
acoustoelastic constant is deduced experimentally from a uniaxial tensile test associated with an ultrasonic measurement (Fig. 5). Acoustoelastic constant represents the slope of the relative variation curve of the time-offlight and the applied stress, as shown in Fig. 6 and Fig. 7.

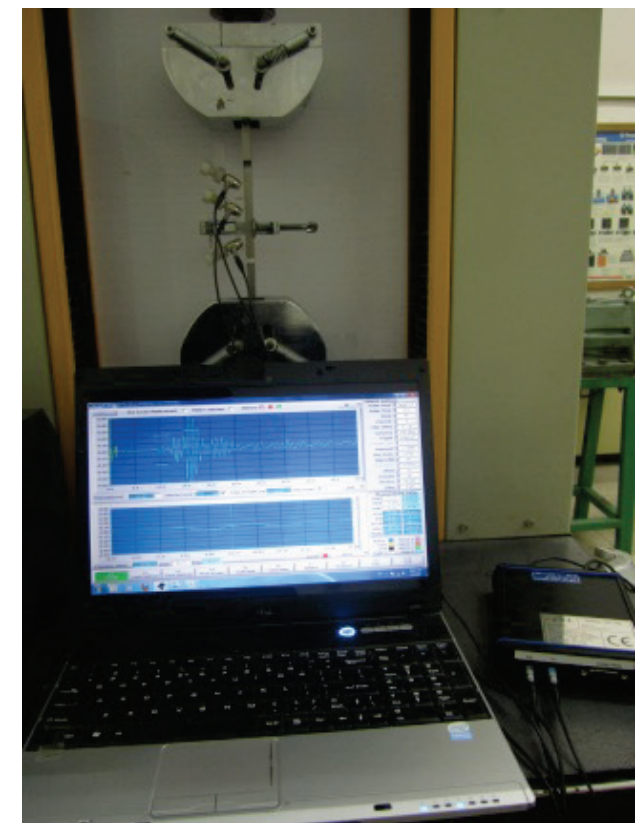

Figure 5 Tensile test to evaluate acoustoelastic constant $L_{11}$

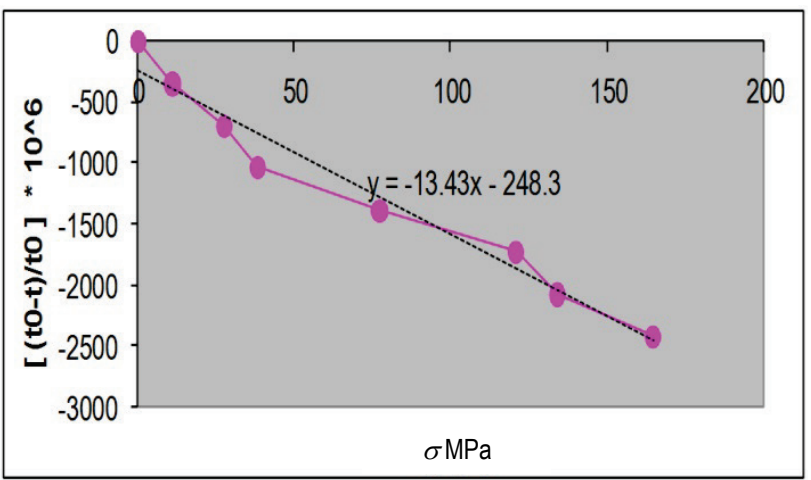

Figure 6 Results of tensile test to evaluate on carbon steel sample

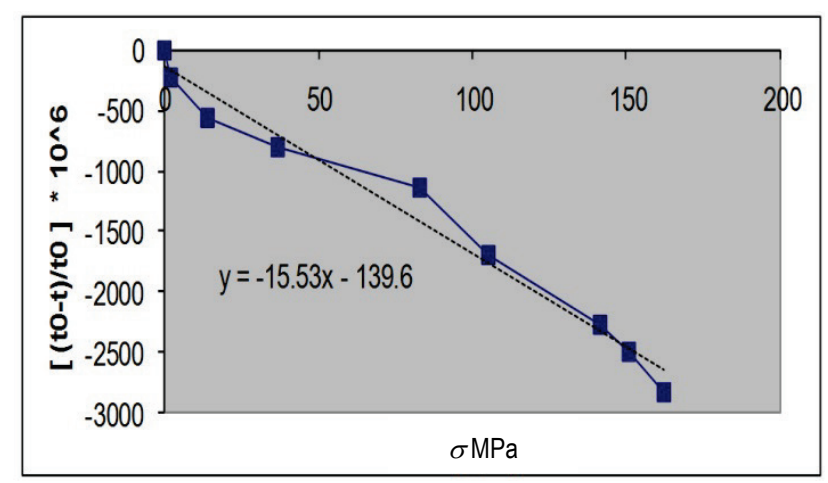

Figure 7 Results of tensile test to evaluate on stainless steel sample

\section{Results and discussion}

In this study, the ultrasonic measurement concerns the residual stresses variations through the thickness of dissimilar welded pipes. The measurements are parallel to the weld axis therefore the hoop residual stress of pipes is evaluated. The values of the residual stresses relating to each weld zone are calculated from the equations $(1) \div(4)$ and the results are shown in Fig. $8 \div 11$.

The characteristics of welding residual stress distribution in the pipe are very complex especially for hoop stresses. The hoop residual stresses distribution which is shown in Fig. $12 \div 13$ and has been extracted from D. Deng [26] is more popular in the references. Fig. 12 shows that, on the inside surface, tensile hoop stresses are generated at the weld zone and its vicinity, and compressive stresses are produced away from the weld centreline [26]. But Fig. 13 shows the distribution of the hoop stress on the outside surface is very complex [26]. From the simulation and experiment results of D. Deng [26], it can be found that the shape is "like a wave and very sensitive to the distance from the weld centreline" [26]. Comparing Fig. 12 and Fig. 13 with residual stress results of this paper, shows reasonable agreement. It can be noticed that the results of $1 \mathrm{Mhz}$ measurement (which is done in $5 \mathrm{~mm}$ from the surface) is similar to the average of the inside and outside surfaces of the pipes especially closer to the inside surface distribution because the thickness of the pipes is $8 \mathrm{~mm}$ and $1 \mathrm{MHz} L_{\mathrm{CR}}$ wave travels nearer to the inside surface. Also, it is obvious from Fig. 9 $\div 11$ that with increasing the frequency (so decreasing the distance from the surface) residual stress distribution became more similar to the hoop stress distribution on the outside surface of the pipes. Also it can be concluded from Fig. $8 \div 11$ that peak of the residual stress in stainless steel side is higher than carbon steel side because of higher yields stress in stainless steel.

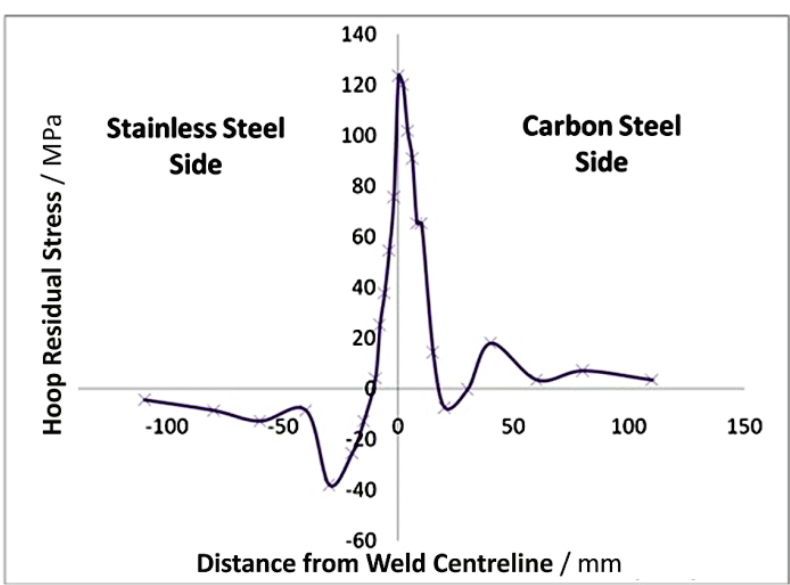

Figure 8 Ultrasonic stress measurement results by $1 \mathrm{MHz} L_{\mathrm{CR}}$ wave

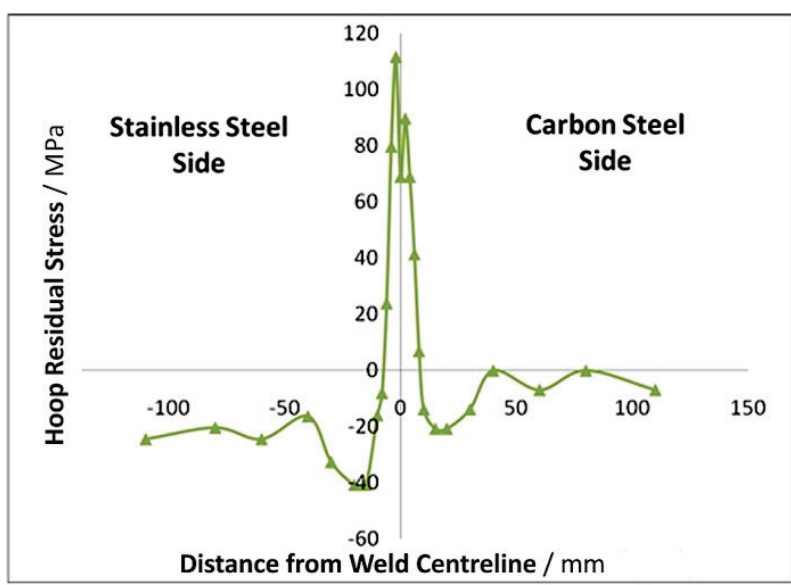

Figure 9 Ultrasonic stress measurement results by $2 \mathrm{MHz} L_{\mathrm{CR}}$ wave 


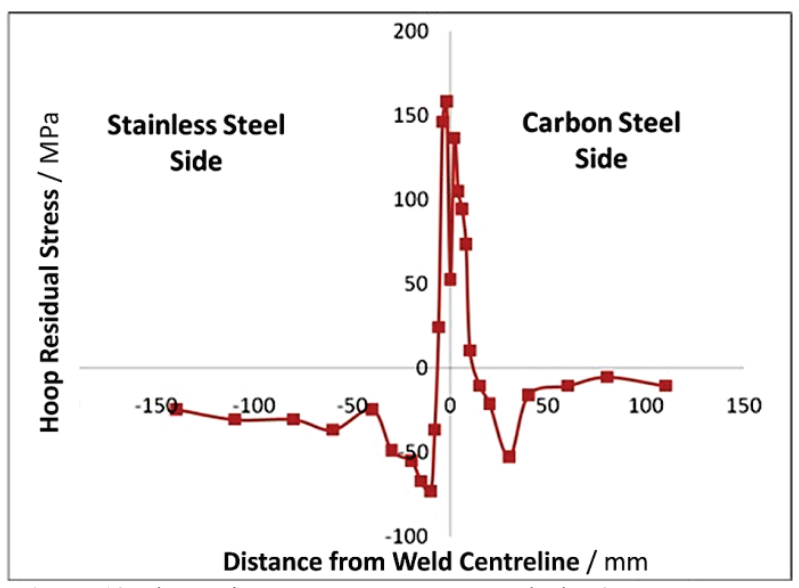

Figure 10 Ultrasonic stress measurement results by $4 \mathrm{MHz} L_{C R}$ wave

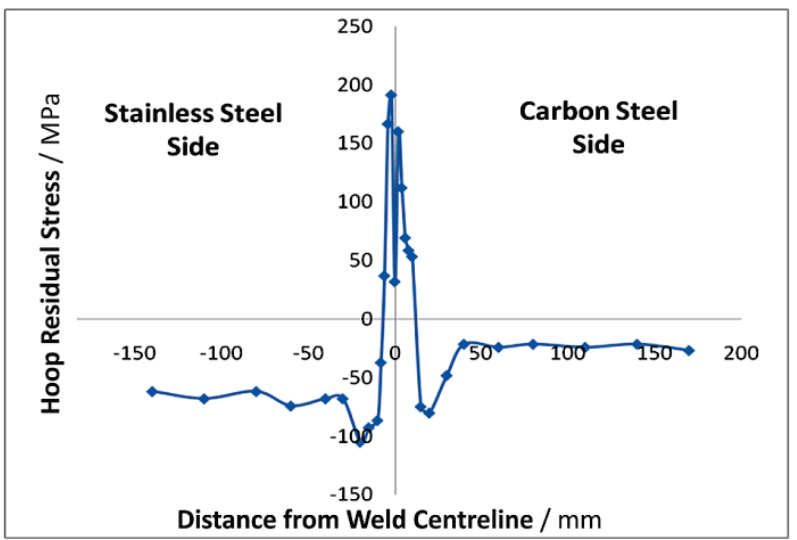

Figure 11 Ultrasonic stress measurement results by $5 \mathrm{MHz} L_{\mathrm{CR}}$ wave

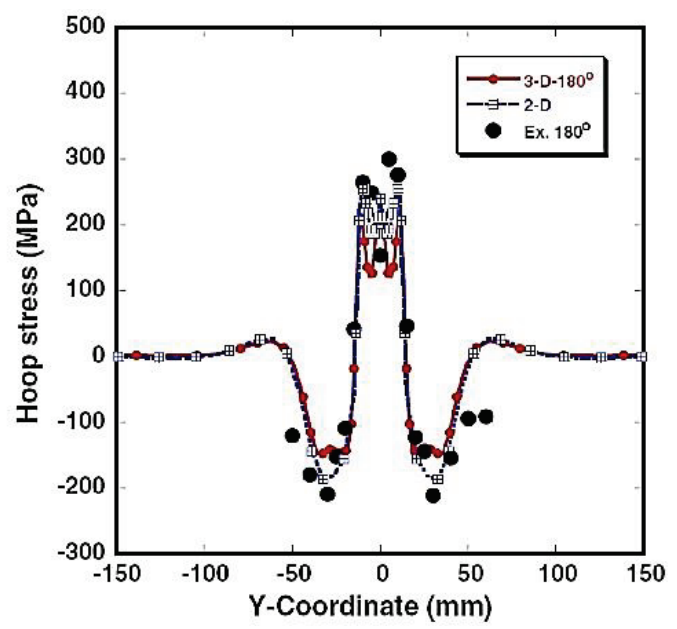

Figure 12 Hoop stress distribution on the inside surface of pipes (extracted from [26])

The other difference between residual stresses of two dissimilar pipes is in residual stress distribution in the points far away from weld centreline. That is because of difference in the thermal conductivity constant between stainless steel and carbon steel. However, this difference is considerably increased by higher frequencies of transducers. To better compare this difference, all of the frequencies are shown in Fig. 14. Generally, higher thermal conductivity of carbon steel causes tensile stress in this zone and compressive stress for the stainless steel side. This manner can be observed in Fig. 8 but, about the other frequencies there is compressive stress in the carbon steel side too, which is probably because of complex distribution of outside hoop stresses.

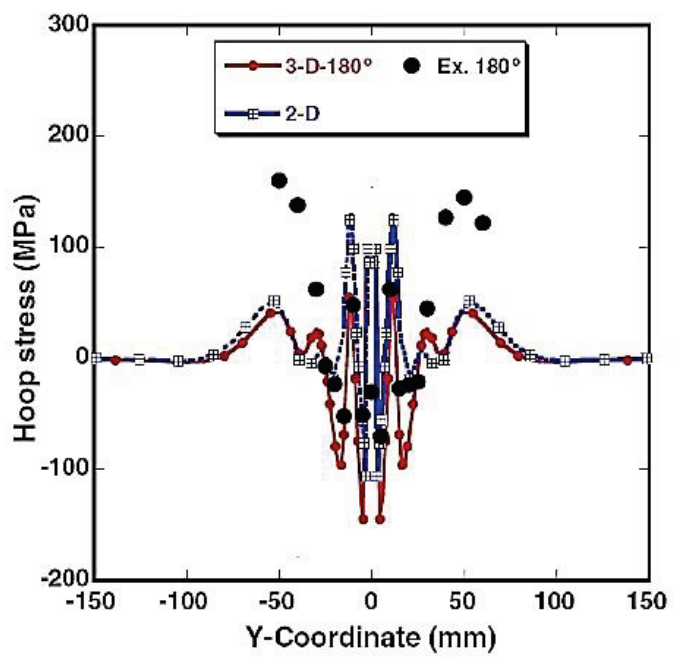

Figure 13 Hoop stress distribution on the outside surface of pipes (extracted from [26])

Residual stress exactly on the weld centreline is shown in Fig. 15. It can be noticed that tensile stress of weld centreline decreases with increasing the frequency. Also, it is obvious from this figure that residual stress near the outer surface (higher frequencies) is more sensitive to the distance from the weld centreline. Therefore the ultrasonic residual stress measurement used in this paper, is capable of inspecting the hoop residual stress variations $n$ the thickness of the dissimilar welded pipes.

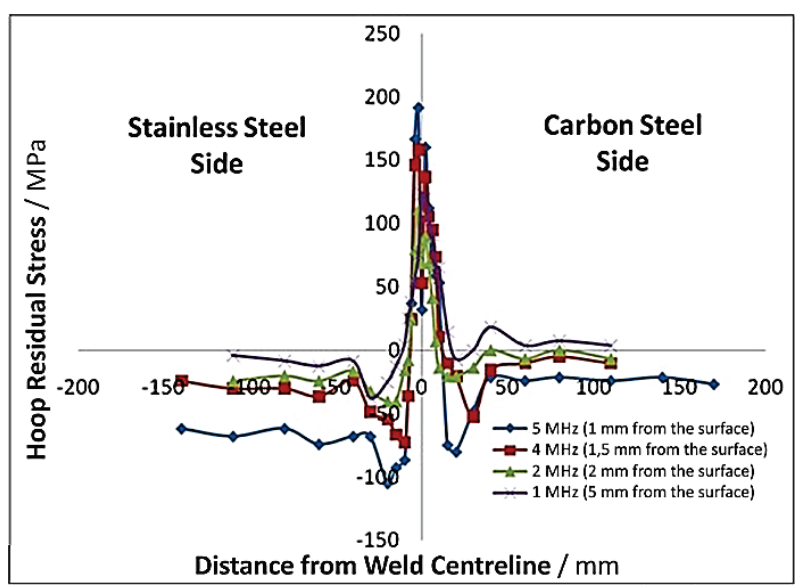

Figure 14 Ultrasonic stress measurement results

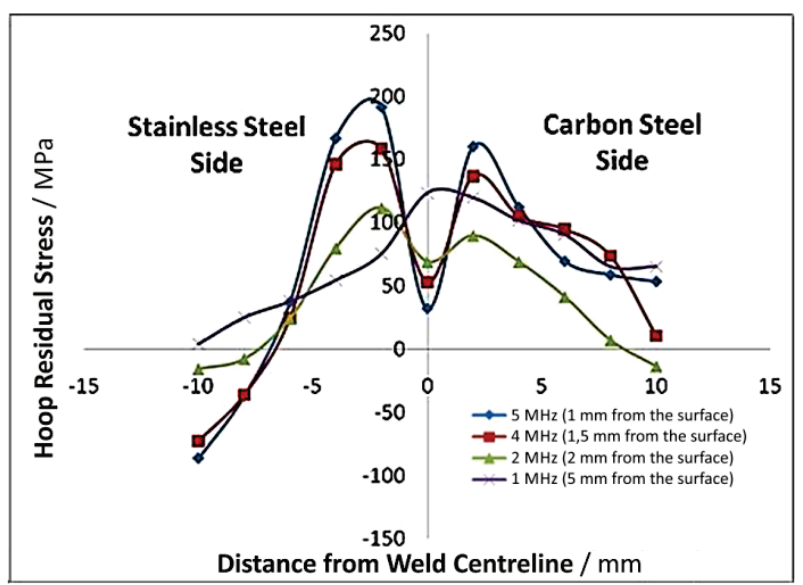

Figure 15 Residual stresses on the weld centreline 


\section{Conclusions}

This paper confirms the potential of the ultrasonic residual stress measurement in inspecting the hoop residual stresses variations in the thickness of dissimilar welded pipes. The results of this paper show that:

1) The hoop residual stress measured on the outside surface of the pipes is very complex and sensitive to the distance from the weld centreline.

2) With increasing the frequency (so decreasing the distance from the surface) residual stress distribution became more similar to the hoop stress distribution of the outside surface of pipes.

3) The peak of residual stress in stainless steel side is higher than carbon steel side because of higher yields stress in stainless steel.

4) Measuring the residual stresses difference between two different materials of dissimilar pipe (in the points far away from the weld centreline) is possible by using the ultrasonic waves. However, this difference is considerably increased by using higher frequencies of transducers.

5) The tensile stress measured in the weld centreline is decreased with increasing the frequency of transducer.

6) Residual stress near the outer surface (measured by using the higher frequencies) is more sensitive to the distance from the weld centreline.

\section{Acknowledgement}

This work was supported by the Slovak Research and Development Agency under the contract No. APVV-20712

\section{References}

[1] Huang, X.M.; Sun, J.; Li, J.F. Effect of Initial Residual Stress and Machining-Induced Residual Stress on the Deformation of Aluminium Alloy Plate. // Strojniski vestnik - Journal of Mechanical Engineering. 61, 2(2015), pp. 131-137. DOI: $10.5545 /$ sv-jme.2014.1897

[2] Urevc, J.; Koc, P.; Stok, B. Numerical Simulation of Stress Relieving of an Austenite Stainless Steel. // Strojniski vestnik - Journal of Mechanical Engineering. 55, 10(2009), pp. 590-599.

[3] Grayli, N.; Shyne J. C. Effect of microstructure and prior austenite grain size on acoustic velocity and attenuation in steel. // Rev Prog NDE. 4, B(1985), pp. 927-936.

[4] Herzer, R.; Schneider, E. Instrument for the automated ultrasonic time-of-flight measurement: A tool for materials characterization. Springer, Berlin/West, 1989.

[5] Palanchamy, P.; Joseph, A.; Jayakumar, T. Ultrasonic velocity measurements for estimation of grain size in austenitic stainless steel. // NDT E Int. 28, (1995), pp. 179185. DOI: 10.1016/0963-8695(95)00011-L

[6] Papadakis, E. P. Physical acoustics and microstructure of iron alloys. // Int Mater Rev, 29, (1984), pp. 1-24. DOl: 10.1179/imr.1984.29.1.1

[7] Hakan Gür, C.; Orkun Tuncer, B. Nondestructive investigation of the effect of quenching and tempering on medium-carbon low alloy steels. // Int J Microstruct Mater Prop. 1, (2005), pp. 51-60. DOI: 10.1504/JJMMP.2005.008130

[8] Ploix, M. A.; Guerjouma, R. E.; Moysan, J.; Corneloup, G.; Chassignole, B. Acoustical characterization of austenitic stainless-steel welds for experimental and modeling. //
NDT J Soc Adv Sci. 17, (2005), pp. 76-81. DOI: 10.2978/jsas.17.76

[9] Spies, M.; Schneider, E. Non-destructive analysis of texture in rolled sheets by ultrasonic techniques. // Text Microstruct. 12, (1990), pp. 219-213. DOI: 10.1155/TSM.12.219

[10] Johnson, G. C. Acoustoelastic response of a polycrystalline aggregate with orthotropic texture.// J Appl Mech. 52, (1985), pp. 659-663. DOI: 10.1115/1.3169117

[11] Sayers, C. M. Ultrasonic velocities in anisotropic polycrystalline aggregates. // J Phys D Appl Phys. 15, (1982), pp. 2157-2167. DOI: 10.1088/0022-3727/15/11/011

[12] Sattari-Far, I.; Javadi, Y. Influence of welding sequence on welding distortions in pipes. // Int J Pressure Vessels and Piping. 85, 4(2008), pp. 265-274. DOI: 10.1016/j.jpvp.2007.07.003

[13] Javadi, Y.; Akhlaghi, M.; Ahmadi Najafabadi, M. Using finite element and ultrasonic method to evaluate welding longitudinal residual stress through the thickness in austenitic stainless steel plates. // Materials and Design. 45, (2013), pp. 628-642. DOI: 10.1016/j.matdes.2012.09.038

[14] Javadi, Y.; Ahmadi Najafabadi, M; Akhlaghi, M. Residual Stress Evaluation in Dissimilar Welded Joints Using Finite Element Simulation and the LCR Ultrasonic Wave. // Russian Journal of Nondestructive Testing. 48, 9(2012), pp. 541-552. DOI: $10.1134 /$ S1061830912090033

[15] Salama, K. Relationship between temperature dependence of ultrasonic velocity and stress. // Quantitative nondestructive evaluation. 1985, pp. 1109-1119

[16] Mohbacher, H.; Schneider, E.; Goebbels, K. Temperature dependence of third-order elastic constants. // Proc 9th international conference on experimental mechanics, 3 , (1990), pp. 1189-1197.

[17] Javadi, Y.; Ahmadi Najafabadi, M. Comparison between contact and immersion ultrasonic method to evaluate welding residual stresses of dissimilar joints. // Materials \& Design. 47, (2013), pp. 473-482. DOI: 10.1016/j.matdes.2012.12.069

[18] Javadi, Y.; Afzali, O.; Raeisi, M. R. H.; Ahmad Najafabadi, M. Nondestructive Evaluation ofWelding Residual Stresses in Dissimilar Welded Pipes. // J Nondestruct Eval. (2013), DOI: 10.1007/s10921-013-0171-2

[19] Egle, D. M.; Bray, D. E. Measurement of acoustoelastic and third order elastic constants for rail steel. // J Acoust Soc Am. 60, (1976), pp. 741-744. DOI: 10.1121/1.381146

[20] Javadi, Y.; Pirzaman, H. S.; Raeisi, M. R. H.; Ahmadi Najafabadi, M. Ultrasonic Evaluation of Welding Residual Stresses in Stainless Steel Pressure Vessel. // Journal of Pressure Vessel Technology. (2013), DOI: 10.1115/1.4023432

[21] Brekhovskii, L. M. Waves in Layered Media. // Academic Press, 1, (1960).

[22] Basatskaya, L. V.; Ermolov, I. N. Theoretical study of ultrasonic longitudinal subsurface waves in solid media. // J Ultrasonics. 27, (1980), pp. 226-233.

[23] Junghans, P.; Bray, D.E. Beam characteristics of high angle longitudinal wave probes. // NDE: Applications, Advanced Methods, and Codes and Standards, Proceedings of ASME Pressure Vessels and Piping Conference / San Diego, 1991, pp. 39-44.

[24] Langenberg, K. J.; Fellenger, P.; Marklein, R. On the nature of the so-called subsurface longitudinal wave and/or the surface longitudinal 'creeping' wave. // Res Nondest Eval. 2, (1990), pp. 59-81. DOI: 10.1080/09349849009409488

[25] Bray, D. E.; Tang, W. Evaluation of Stress Gradients in Steel Plates and Bars with the LCR Ultrasonic Wave. // Nuclear Engineering and Design, 207, (2001), pp. 231-240. DOI: 10.1016/S0029-5493(01)00334-X

[26] Deng, D.; Murakawa, H. Numerical simulation of temperature field and residual stress in multi-pass welds in 
stainless steel pipe and comparison with experimental measurements. // Computational Materials Science, 2005.

\section{Authors' addresses}

\section{Yashar Javadi}

Department of Mechanical Engineering,

Islamic Azad University - Semnan Branch,

$5 \mathrm{~km}$ of Semnan-Damghan Road, Semnan, Iran

E-mail: yasharejavadi@yahoo.com

\section{Grzegorz M. Krolczyk}

Faculty of Mechanical Engineering,

Opole University of Technology,

76 Prószkowska Street, 45-758 Opole, Poland

E-mail:g.krolczyk@po.opole.pl

\section{Sergej Hloch, Prof., Ing., PhD.}

Faculty of Manufacturing Technologies TU of Košice with the seat

in Prešov, Bayerova 1, 08001 Prešov, Slovak Republic

E-mail: hloch.sergej@gmail.com 